\title{
O.Y. Nechytaylo, V.M. Konovchuk \\ THE PLACE OF SENSORY NEUROPATHY IN THE PATHOGENESIS OF CRITICAL LIMB ISCHEMIA IN DIABETIC PATIENTS
}

Higher State Educational Institution of Ukraine «Bukovinian State Medical University» (Chemivtsi)

\begin{abstract}
In the article peculiarities of sensory neuropathy in 47 diabetic patients with and without surgical complications of the lower extremities have been studied. The simple clinical screening technique for diabetic neuropathy which included four tests: tactile and pain sensation, vibration perception, presence and level of Achilles reflex was used. Manifestations of neuropathy included the most common symptoms such as numbness, prickling, aching, decreased thermal sensation and burning. Approximately $75 \%$ of all study subjects had sensory neuropathy
\end{abstract}

The prevalence of diabetes mellitus is rising all over the world. Diabetes has a lot of different complications affecting the heart, kidneys, eyes, nerves and feet $[1,2]$. One of the main causes of diabetic complications is a decrease of blood supply as a result of vascular pathology on both levels - macroand microcirculation. Complications of feet are the most frequent problems of diabetes and key contributors to the medical and financial implications as nearly half of all hospitalizations due to diabetes are the feet complications [2, 3]. The diabetic foot syndrome (DFS) is defined, according to the WHO, as "ulceration of the foot associated with neuropathy and different grades of ischemia and infection" [3]. DFS represents serious long-term consequences of diabetes leading to disability. The complications of foot ulcers are the major cause of hospitalization and amputation in diabetic patients and lead to significant health care costs as evidenced by the fact that $20-40 \%$ of health care resources for diabetes are spent on DFS $[1,2]$.

It has been recognized that the leading causes of feet ulcerations are microcirculation changes and diabetic neuropathy. Diabetic peripheral neuropathy (DPN) is an impairment of normal activities of the nerves throughout the body and which could alter autonomic, motor and sensory functions [7]. The lifetime incidence of neuropathy is approximately $45 \%$ for patients with type 2 diabetes. According to the multicenter study, the most frequent component in the causal sequence to ulceration in diabetic patients was sensory neuropathy. In sensory neuropathy the lack of protective sensation makes the foot vulnerable to unattended minor injuries caused by an excess of pressure and mechanical or thermal injury. At present, an underdiagnosis of DPN is a fundamental issue and impedes the prevention of neuropathy-related sequels [4]. Studies of nerve conduction tests performed at the time of diabetes diagnosis demonstrate that in many cases neuropathy is already present in patients in subclinical forms. Early diagnosis of DPN is necessary in cases of small fiber neuropathy or subclinical diabetic neuropathy when

(C) O.Y. Nechytaylo, V.M. Konovchuk, 2017
(47,1 \% patients without surgical complications and 88,9\% patients with complications in the lower extremities). The pathogenesis of critical limb ischemia in general is complex and includes impaired glycemic control, microcirculation deterioration and neuropathy. The study established that sensory neuropathy is one of the main causative factors in critical limb ischemia and development of diabetic foot syndrome.

Key words: diabetes, sensory neuropathy, angiopathy, diabetic foot syndrome.

pathology may be reversed or significantly improved with appropriate intervention. New information about the pathogenesis of DPN continues to emerge, which will lead to identifying new drug targets [6, 7]. Recently, there has been a greater emphasis placed on identifying patients who are at an elevated risk for developing DPN. But pathogenesis of DFS depends on many factors and in some cases DPN could be subclinical or even absent, associated or not with severe microcirculation disorders or other factors. This is important because knowledge of role of different cause's combinations could help earlier diagnosis and improve control of diabetes related complications [3].

Objective: The aim of the current study was to examine the correlation between neuropathy and clinical features of DFS in subjects with type 2 diabetes.

Materials and methods. In total 47 patients aged 43-82 years (mean age - 64,7 $\pm 1,3$ years, $66,0 \%$ men and $34,0 \%$ women) were involved in the study. The patients were subdivided in 2 groups the first group with type 2 diabetes without DFS (19 patients) and the second one- with DFS (28 patients). Clinical and paraclinical investigations were conducted. Infrared thermometry of low limbs and sublingual biomicroscopy were performed by means of digital devices. We used simple clinical screening technique for diabetic neuropathy which included four tests: tactile and pain sensation, vibration perception, presence and level of Achilles reflex. The subjects were requested to remove their shoes and socks and to lie supine on a couch for at least 5 minutes before the measurements were made. The foot was kept warm during the measurement and the room temperature was about $22^{\circ} \mathrm{C}$. Tactile and pain sensation were assessed by the monofilament smooth motion on the dorsum of the first toe and needle pricking just proximal to the nail bed of the toe. Vibration testing was conducted using a $128-\mathrm{Hz}$ tuning fork applied to the bony prominence at the dorsum of the first toe. The patient reported perception of both the start and cessation of the vibration sensation con- 
ducted twice on each toe, and the score (between 0 and 2) was defined as absent, shorter than 10 seconds and longer than 10 seconds. The score for each test was defined on three grades: 0 (absent), 1 (decreased) and 2 (normal). The total score of all tests was between 0 and 8 . Four severity strata were defined, including no neuropathy (7-8), mild neuropathy (5-6), moderate neuropathy (3-4) and severe neuropathy (0-2) according to the total score. The patients were treated with either oral hypoglycemic agents or insulin. Data statistical analysis was conducted by using the software Statistica (version 5.11, StatSoft Inc.). The data were expressed as mean \pm standard error for quantitative variables and as numbers and percentages for categorical variables. Statistical analysis was performed using the Student's t-test for numerical variables. All $\mathrm{p}$-values were two-tailed and $\mathrm{p}<0.05$ was considered statistically significant.

Results of the research and their discussion. Approximately $75 \%$ of all experimental subjects had sensory neuropathy. The majority of such patients noted mild to moderate discomfort associated with the neuropathy. Manifestations of neuropathy included the most common presentation of diabetic neuropathy such symptoms as numbness, prickling, aching, burning and decreased of thermal sensation. Subjectively patients initially experience sensory decrease in the toes and feet. There could be weakness of the toe flexor and extensor muscles but significant weakness was not a common finding in early diabetic neuropathy. The pain could be provoked by activity but was often worst at night. Some patients reported deep aching pain, vasomotor changes (pallor alternating with rubor or cyanosis). The presence of cardiac autonomic neuropathy was in 3 cases with symptoms of resting tachycardia, palpitations and orthostatic hypotension. Muscle strength and reflexes in these cases were often normal. According to opinion of J.W. Russell just small fiber neuropathy is characterized by superficial burning pain in the feet caused by preferential involvement of the small unmyelinated nerve fibers that mediate pain, tem- perature sensation and autonomic functions [4]. Small fiber neuropathies may not have any abnormalities on nerve conduction studies and could be further evaluated only with skin biopsy.

In our patients we assessed clinical screening tests for diabetic neuropathy: tactile and pain sensation, vibration perception and level of Achilles reflex. We found out some asymmetry in test results right legs had dipper changes of sensation (fig. 1). Small myelinated and unmyelinated fibers convey sensations of light touch, pain, and temperature, while large fibers are responsible for vibratory sensation and joint position sense. The lowest level of sensation was just in vibration perception which shows on large fibers problems.

In our investigation dominated mild neuropathy, severe and moderate forms of neuropathy were in one third of cases (fig. 2).

It was typically a slow progressive sensory predominant neuropathy. Diabetic subjects with neuropathy were older and had longer duration of diabetes. The degree of neuropathy in our study correlated with age $(\mathrm{r}=0,44, \mathrm{p}<0,05)$, duration of disease $(\mathrm{r}=0,45, \mathrm{p}<0,05)$, level of diastolic blood pressure $(\mathrm{r}=-0,28, \mathrm{p}<0,05)$ and local skin temperature $(\mathrm{r}=$ $0,35, \mathrm{p}<0,05)$.

The comparison between groups show presence of neuropathies in $47,1 \%$ patients of the first group and $88,9 \%$ in patients with DFS $(p<0,05)$. The total score of neuropathy severity in the first group was $5,5 \pm 0,57$ (mild neuropathy) in comparison with $3,8 \pm 0,45$ (moderate) in the second $(p<0,05)$. The patients with DFS had higher level of blood glucose $(11,3 \pm 0,82$ and $9,9 \pm 0,78) \quad(\mathrm{p}<0,05)$ and systolic blood pressure $-138,6 \pm 3,02 \mathrm{~mm} \mathrm{Hg}$ in comparison with $128,2 \pm 2,1 \mathrm{~mm} \mathrm{Hg}(\mathrm{p}<0,05)$. In patients with neuropathy in sublingual microcirculation pictures presence of capillaries with irregular morphology and avascular areas were more frequently seen.

It is important, that some patients with diabetic neuropathy are unaware of their sensory loss and could experience painless injuries and they are at

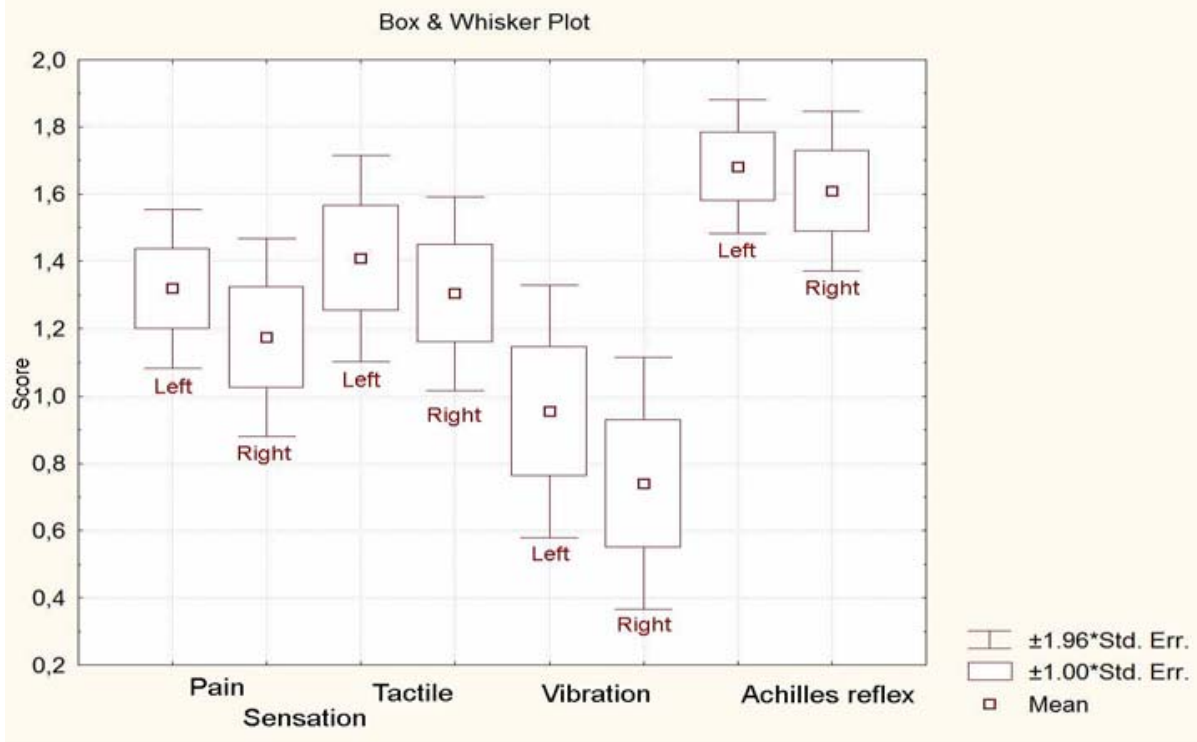

Fig. 1. Results of clinical screening methodic for diabetic neuropathy 


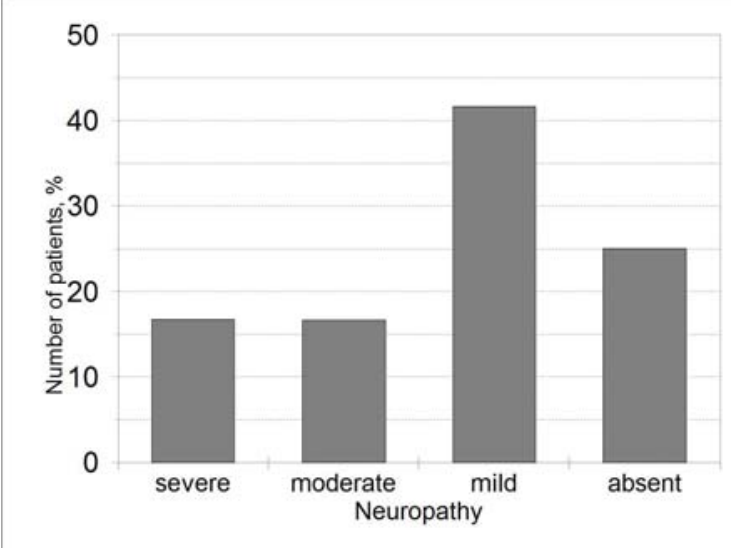

Fig. 2. Incidence of sensory neuropathy forms in diabetic patients

higher risk of falls because of sensory loss and impaired proprioception. It also indicated that the presence of cardiac autonomic neuropathy is associated with a two to five times increased risk of all-cause mortality. Symptoms of resting tachycardia, palpitations, exercise intolerance, or orthostatic hypotension may indicate cardiac autonomic neuropathy [4].

Thus, the pathogenesis of DFS in general is complex and includes impaired glycemic control, microcirculation deterioration and sensory neuropathy. It is clear that any increase in glucose above normal is associated with higher risk of different organs injury, including neuropathy. Strict glucose control could delay the onset or slow the progression of diabetic neuropathy.

\section{Conclusions}

1. The diabetic sensory neuropathy is one of causative factors in critical limb ischemia and development of DFS. The pathogenesis of DFS in general is complex and includes impaired glycemic control, microcirculation deterioration and sensory neuropathy.
2. The simple clinical screening technique which included four tests: tactile and pain sensation, vibration perception, presence and level of Achilles reflex is effective to diagnose diabetic sensory neuropathy.

3. Diabetic patients with insensate feet are especially prone to developing foot ulcerations. Early diagnostic of sensory neuropathy and sanitary education regarding proper foot care is especially important for such patients.

Prospects for further research. To establish an influence of other factors such as microcirculation changes in following clinical examination. The possible pathogenic role of elevated systemic arterial pressure could be also studied.

\section{References}

1. Паньків В.I. Цукровий діабет: діагностичні критерії, етіологія і патогенез / В.I. Паньків // Междунар. эндокринол. ж. - 2013. - № 8. - С. 53-64.

2. Дедов И.И. Сахарный диабет - опаснейший вызов мировому сообществу / И.И. Дедов // Вестн. РАМН. 2012. - № 1. - C. 7-13.

3. Jeffcoate W.J. The description and classification of diabetic foot lesions / W.J. Jeffcoate, R.M. Macfarlane, E.M. Fletcher // Diabetic Medicine. - 1993. - Vol. 10, № 7. - P. 676-679.

4. Russell J.W. Diabetic neuropathies / J.W. Russell, L.A. Zilliox // Continuum. - 2014. - № 20 (5). P. 1226-1240.

5. The effects of capillary dysfunction on oxygen and glucose extraction in diabetic neuropathy / L. Østergaard, N B. Finnerup, A.J. Terkelsen [et al.] // Diabetologia. 2015. - № 58 (4). - P. 666-677.

6. Diabetic neuropathies: update on definitions, diagnostic criteria, estimation of severity, and treatments / S. Tesfaye, A.J.M. Boulton, P.J. Dyck [et al.] // Diabetes Care. 2010. - № 33 (10). - P. 2285-2293.

7. Diabetic neuropathy: Clinical manifestations and current treatments / B.C. Callaghan, H. Cheng, C.L. Stables [et al.] // Lancet Neurol. - 2012. - № 11 (6). - P. 521-534.

\section{МЕСТО СЕНСОРНОЙ НЕЙРОПАТИИ В ПАТОГЕНЕЗЕ КРИТИЧЕСКОЙ ИШЕМИИ НИЖНИХ КОНЕЧНОСТЕЙ У БОЛЬНЫХ САХАРНЫМ ДИАБЕТОМ}

\section{Е.Ю. Нечитайло, В.Н. Коновчук}

Резюме. В статье рассмотрены особенности сенсорной нейропатии у 47 пациентов с сахарным диабетом с наличием хирургических осложнений со стороны нижних конечностей и без них. Использована простая клиническая скрининговая методика для выявления диабетической нейропатии, которая включала четыре теста: определение тактильной и болевой чувствительности, восприятие вибрации, наличие и уровень Ахиллова рефлекса. Проявления невропатии включали наиболее распространенные симптомы: онемение, покалывание, ноющие боли, снижение тепловой чувствительности, ощущение жжения. Около $75 \%$ всех обследованных имели сенсорную нейропатию (47,1 \% пациентов без хирургических осложнений и 88,9 \% пациентов с осложнениями со стороны нижних конечностей). Патогенез критической ишемии нижних конечностей в целом является сложным и включает нарушения гликемического контроля, ухудшение микроциркуляции крови и нейропатию. В исследовании установлено, что сенсорная нейропатия является одним из главных причинных факторов в развитии критической ишемии нижних конечностей и синдрома диабетической стопы.

Ключевые слова: сахарный диабет, сенсорная нейропатия, ангиопатия, синдром диабетической стопы. 


\section{МІСЦЕ СЕНСОРНОЇ НЕЙРОПАТІЇ У ПАТОГЕНЕЗІ КРИТИЧНОЇ ІШЕМІЇ НИЖНІХ КІНЦІВОК У ХВОРИХ НА ЦУКРОВИЙ ДІАБЕТ}

\section{О.Ю. Нечитайло, В.М. Коновчук}

Резюме.У статті розглянуто особливості сенсорної нейропатії у 47 пацієнтів із цукровим діабетом з наявністю хірургічних ускладнень з боку нижніх кінцівок та без них. Використана проста клінічна скринінгова методика для виявлення діабетичної нейропатії, яка включала чотири тести: визначення тактильної і больової чутливості, сприйняття вібрації, наявність і рівень Ахіллового рефлексу. Прояви невропатії включали найбільш поширені симптоми: оніміння, поколювання, ниючі болі, зниження теплової чутливості, відчуття печіння. Близько 75 \% всіх обстежених мали сенсорну нейропатію (47,1 \% пацієнтів без хірургічних ускладнень і 88,9 \% пацієнтів з ускладненнями 3 боку нижніх кінцівок). Патогенез критичної ішемії нижніх кінцівок, у цілому, є складним і включає порушення глікемічного контролю, погіршення мікроциркуляції крові та нейропатію. У дослідженні встановлено, що сенсорна нейропатія - один із головних причинних факторів у розвитку критичної ішемії нижніх кінцівок та синдрому діабетичної стопи.

Ключові слова: цукровий діабет, сенсорна нейропатія, ангіопатія, синдром діабетичної стопи.

Вищий державний навчальний заклад України «Буковинський державний медичний університет», м. Чернівці 